\title{
Historiografia e Terapia na Cidade da Linguagem de Wittgenstein*
}

\author{
Historiography and Therapy in Wittgenstein's City of Language
}

\author{
Antonio Miguel $^{* *}$
}

\begin{abstract}
Resumo
O propósito deste artigo é problematizar o papel da filosofia na pesquisa historiográfica em Educação Matemática. Para isso, fazemos a filosofia terapêutico-gramatical do filósofo austríaco Ludwig Wittgenstein contracena com a filosofia desconstrucionista do filósofo franco-argelino Jacques Derrida, sobretudo em referência a um aforismo das Investigações Filosóficas, de Wittgenstein, que compara a nossa linguagem a uma cidade antiga.
\end{abstract}

Palavras-chave: Pesquisa Historiográfica. Educação Matemática. Terapia Wittgensteiniana. Desconstrucionismo Derridiano.

\begin{abstract}
The purpose of this article is to discuss the role of philosophy in the historiographical research in mathematics education. For this purpose, we make the therapeutic grammatical philosophy of Austrian philosopher Ludwig Wittgenstein act with the deconstructionist philosophy of French-Algerian philosopher Jacques Derrida, especially in reference to an aphorism of Wittgenstein's Philosophical Investigations comparing our language to an ancient city.
\end{abstract}

Keywords: Historiographical Research. Philosophy of Mathematics Education. Wittgensteinian Therapy. Derridean Deconstructionism.

Neste artigo, temos como propósito problematizar o papel da Filosofia na pesquisa historiográfica - e, particularmente, na pesquisa historiográfica em Educação Matemática fazendo o que tem sido denominada a filosofia terapêutico-gramatical do filósofo austríaco Ludwig Wittgenstein contracenar com a filosofia desconstrucionista do filósofo francoargelino Jacques Derrida, sobretudo em referência ao aforismo do parágrafo 18 das

\footnotetext{
* Texto baseado em apresentação oral, com título homônimo, feita pelo autor na Mesa Redonda intitulada "História da Educação Matemática: o que a Filosofia tem a ver com isso?", ocorrida em 19 de julho de 2013, no XI Encontro Nacional de Educação Matemática (XI ENEM - Curitiba-PR-2013). Os demais integrantes dessa mesa foram os professores: Antonio Vicente M. Garnica (coordenador); Arlete de Jesus Brito e Carlos Roberto Vianna.

** Professor Livre-docente do Departamento de Ensino e Práticas Culturais da Faculdade de Educação da Universidade Estadual de Campinas (UNICAMP). Endereço para correspondência: Rua Jader Passos, 374, casa 37, CEP: , Campinas/SP. Email: miguel37.unicamp@gmail.com
} 
Investigações Filosóficas de Wittgenstein (1986) que compara a nossa linguagem a uma cidade antiga ${ }^{1 .}$

Penso estarmos todos cientes da longevidade do debate acadêmico relativo aos papéis da Filosofia na pesquisa historiográfica. Sabemos também que um dos efeitos de maior força desse debate foi a disseminação da imagem do poder constituinte e fundante do discurso filosófico em relação às práticas de pesquisa historiográfica. Poderíamos então perguntar: essa imagem de poder poderia também ser vista como poder dessa imagem? Para investigar isso, vamos nos por nos rastros do pensamento de Wittgenstein:

Uma imagem nos mantinha presos. E não pudemos dela sair, pois ela residia em nossa linguagem, que parecia apenas repeti-la para nós inexoravelmente (WITTGENSTEIN - IF- $§ 115$ ).

Seria possível desafiar o poder dessa imagem? A questão que estamos aqui submetendo à investigação envolve outros campos do conhecimento como a Educação e a Matemática. Isso parece tornar o debate mais complexo, sobretudo, porque essa imagem de poder do discurso filosófico parece impactar de modos diferentes a pesquisa nos campos isolados da Educação e da Matemática e, por extensão, nos campos da Educação Matemática e da história da Educação Matemática. Inspirando-me sobretudo em Wittgenstein, quero aqui sugerir uma reorientação radical da natureza desse debate. Observemos a imagem ${ }^{2}$ seguinte e atentemo-nos para o que Wittgenstein nos diz sobre a filosofia:

\footnotetext{
${ }^{1}$ Por ter sido esta investigação inicialmente realizada com o propósito de se produzir um texto a ser apresentado oralmente e debatido em evento científico, a decisão que tomamos em apresentá-la sob a forma de artigo acadêmico procurou manter - no corpo do texto deste artigo - o tom coloquial, conciso e informal da sua comunicação oral original. Entretanto, a fim de não comprometer a fluência dessa comunicação, procuramos também resgatar, nas notas de rodapé deste texto, o tom dialógico-remissivo, esclarecedor e argumentativo requerido por um artigo acadêmico. Por essa razão, a maior parte das notas ficou extensa e densa. Sugerimos que tais notas sejam vistas e lidas como igualmente integrantes do artigo e indispensáveis para uma compreensão mais aguda do problema que nele é enfocado e do tratamento dispensado a tal problema.

${ }^{2}$ Ilustração de Jhonata Alves L. Veronezi que acompanha a matéria de Ricardo Bonalume Neto, publicada no jornal paulista Folha de S. Paulo, de 15/06/2013, na seção Cotidiano 1 - C4.
} 


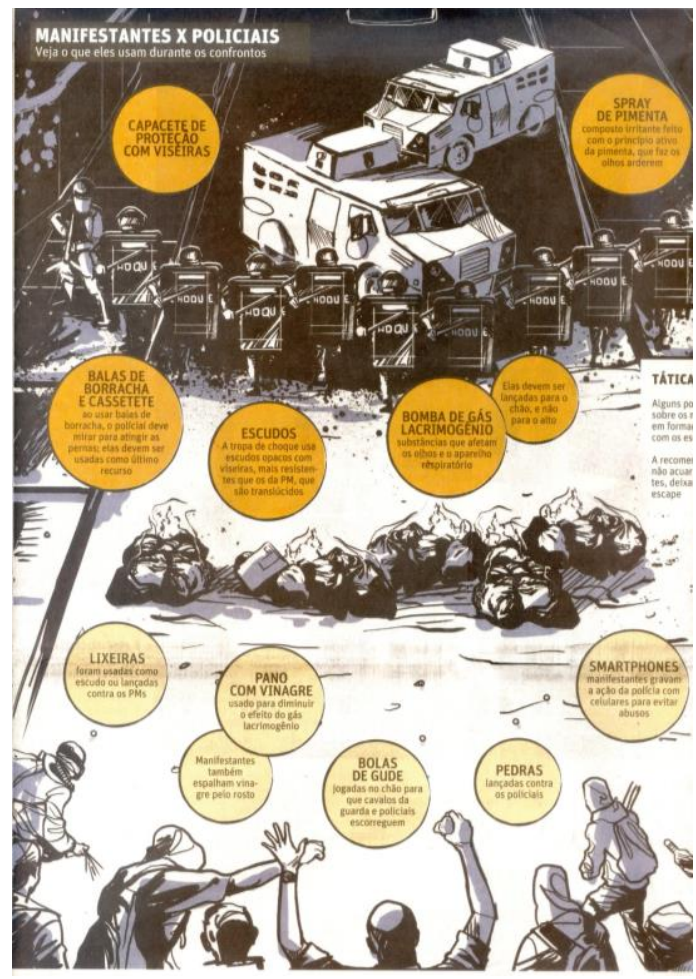

Um problema filosófico tem a forma: "Eu não sei mais nada" (WITTGENSTEIN - IF-§ 123).

A filosofia simplesmente coloca as coisas, não elucida nada e não conclui nada. Como tudo fica em aberto, não há nada a elucidar [...] (WITTGENSTEIN - IF-§ 126).

A filosofia não deve, de modo algum, tocar no uso efetivo da linguagem; em último caso, pode apenas descrevê-lo. Pois também não pode fundamentá-lo. A filosofia deixa tudo como está [...] (WITTGENSTEIN IF-§ 124, itálicos nossos).

A imagem acima remete a um acontecimento de nossa história. Ela é uma ilustração midiática de uma cena que suspende, no tempo, a iminência de um confronto entre manifestantes e policiais. Associei esta imagem àquela que Wittgenstein faz da filosofia, porque ela me parece representar bem a batalha incansável travada por esse filósofo contra os modos metafísicos de pensar. Se as passagens mencionadas parecem sugerir que Wittgenstein estaria reduzindo, até quase ao esvaziamento, a importância e o propósito da Filosofia, as que se seguem parecem sugerir que ele estaria, na verdade, redefinindo o seu papel:

Qual é o seu objetivo em filosofia?

- Mostrar à mosca a saída do vidro (WITTGENSTEIN - IF-§ 309).

Os resultados da filosofia consistem na descoberta de um simples absurdo qualquer e nas contusões que o entendimento recebeu ao correr de encontro às fronteiras da linguagem. Essas contusões nos permitem reconhecer o valor dessa descoberta (WITTGENSTEIN - IF-§ 119).

[...] Não há um método da filosofia, mas sim métodos, como que diferentes terapias (WITTGENSTEIN - IF-§ 133, itálicos do autor).

Parece, então, que, ainda que a Filosofia quase nada possa fazer, pode ainda fazer alguma coisa. O quê? Levar-se e levar ao divã todos os discursos que façam "maus usos da linguagem" e submetê-los a diferentes terapias locais que os tratem diferentemente como "doenças" diferentes. E por "maus usos da linguagem” deve-se entender "usos metafisicos da linguagem", isto é, usos que produzem pseudoproblemas que, por ultrapassarem os limites e os poderes da linguagem, não podem, por essa razão, receber esclarecimentos adequados 
por nenhum outro recurso humano. Daí, ser o propósito de tais terapias o de dissolvê-los enquanto problemas. Mas, como? Ouçamos Wittgenstein:

\begin{abstract}
Poder-se-ia pensar que quando a filosofia fala do uso da palavra "filosofia", deveria haver uma filosofia de segunda ordem. Mas isso não se dá [...] (WITTGENSTEIN IF-§ 121)
\end{abstract}

Quando falo da linguagem devo falar a linguagem do cotidiano (WITTGENSTEIN - IF-§ 120, itálicos nossos).

\begin{abstract}
Quando os filósofos usam uma palavra - "saber", "ser", "objeto", "eu", "proposição", "nome" - e procuram apreender a essência da coisa, deve-se sempre perguntar: essa palavra é usada de fato desse modo na língua em que existe? - Nós reconduzimos as palavras do seu emprego metafísico para seu emprego cotidiano (WITTGENSTEIN - IF-§ 116, itálicos do autor).
\end{abstract}

Esta luta contra usos metafísicos da linguagem leva Wittgenstein a uma valorização sem precedentes dos usos cotidianos da linguagem. Isso porque, para ele, os usos especializados não podem se constituir autonomamente, independentemente dos usos ordinários da linguagem. E, ao considerar os modos como as pessoas praticam ordinariamente a linguagem, Wittgenstein sugere que essas práticas, para se tornarem significativas, não podem ser desligadas das ações corporais situadas dos seus próprios praticantes. De fato, para ele, "Palavras são também ações" (WITTGENSTEIN, IF-§546). E, num aforismo que nos remete a rastros de significado do Fausto, de Goethe, não só esclarece os laços de continuidade e não dissociabilidade entre jogos de linguagem e ações corporais, como também sugere o primado e a conexão, ainda que remota, destas últimas em relação a formas abstratas e supostamente incorpóreas de se praticar a linguagem: "A linguagem - gostaria de o dizer - é um aperfeiçoamento, no princípio era a ação" (WITTGENSTEIN, 2000, p. 53, itálicos meus).

Wittgenstein sugere também que a linguagem não é usada de modo unitário e uniforme, mas de modos ilimitadamente heterogêneos e nem sempre regrados ${ }^{3}$. Esses usos da linguagem são denominados jogos de linguagem e são eles que indicam, em cada situação

\footnotetext{
${ }^{3}$ Denominaremos tais jogos não regrados de linguagem de agramaticais, querendo com isso sugerir que tais jogos podem ser praticados sem a orientação de uma gramática. Por sua vez, utilizaremos a palavra "gramática" de um modo personalizado - porém inspirado em modos nem sempre intercambiáveis como o próprio Wittgenstein a utiliza -, sobretudo, para significar o conjunto não essencialista e variável de regras ou enunciados normativos, nem sempre identificáveis de forma clara e incontroversa, que orientam o sentido das ações na encenação de um jogo de linguagem, em um determinado contexto de atividade humana. Segundo Glock (1998, p. 195, itálicos do autor), para Wittgenstein, "a gramática determina que espécie de objeto alguma coisa é, uma vez que especifica o que pode ser dito com sentido sobre ele. [...] A resposta à pergunta socrática "O que é X?" não nos é dada pelo exame de essências (objetos mentais ou abstratos), mas pelo esclarecimento do significado de "X" que é fornecido pelas regras para o uso de "X" ". Embora o termo agramatical pareça não ter sido utilizado por Wittgenstein, pensamos que ele nos fornece, em sua obra, exemplos de jogos de linguagem que consideramos agramaticais, tais como o seguinte: "Numa conversa: uma pessoa atira uma bola; a outra não sabe se deve atirá-la de volta ou atirá-la a uma terceira pessoa, ou deixá-la no chão, ou apanhá-la e pô-la no bolso etc." (WITTGENSTEIN, 2000, p. 110).
} 
contextual em que são praticados, os sentidos variáveis de palavras, objetos e das próprias ações corporais que esses jogos encenam:

$\mathrm{Na}$ práxis do uso da linguagem, um parceiro enuncia as palavras, o outro age de acordo com elas. [...] chamarei de jogos de linguagem o conjunto da linguagem e das ações com as quais está interligada (WITTGENSTEIN, IF-§7).

Este modo de Wittgenstein falar da linguagem vem logo após um exemplo de jogo de linguagem no qual cada palavra enunciada por um pedreiro é seguida de uma ação do seu ajudante que lhe passa o material de construção solicitado. Assim, a linguagem vista como práxis sugere que praticar um jogo de linguagem se assemelha a participar de uma encenação, de uma performance corporal efetiva. O que Wittgenstein está querendo dizer com isso é que sempre praticamos a linguagem com o corpo todo, e não apenas com a vibração culturalmente regrada de sons emitidos por nossas cordas vocais.

Pensamos, portanto, não ser arbitrário este nosso modo de ver os jogos de linguagem, assimilando-os, sempre, a jogos de cena, o que nos permite, a partir de agora, usar de modo intercambiável as expressões “jogos de linguagem” e "encenações da linguagem”. De fato, já assinalamos, em outro contexto (MIGUEL, 2014), que Wittgenstein era leitor e admirador do filósofo, astrônomo e matemático alemão Georg-Christoph Lichtenberg (1744-1799), de cuja obra aforística o filósofo - tal como também o fizeram Kant, Schopenhauer, Nietzsche, Freud e Tolstoi - provavelmente também se inspirou para a redação do seu Tractatus e das suas Investigações Filosóficas. Lichtenberg, ao longo de sua vida, ocupou-se, dentre outros, de problemas tais como os das relações entre o corpo e a mente, a razão e o sentimento, a linguagem e o pensamento, o homem e a mulher, a ideia e a realidade. Lichtenberg empreendeu essa reflexão através de uma escrita literária carregada de humor refinado e ironia sutil, tal como o atesta o seguinte aforismo: "Tenho observado frequentemente que sinto dor de cabeça quando me contemplo por longo tempo em um espelho côncavo" (LICHTENBERG, 1966, p. 43).

A Matemática e os matemáticos de sua época também não escaparam ao seu agudo olhar crítico:

Na lei 2 vezes 2, 4 ou $2.2=4$, há já, verdadeiramente, alguma coisa da paralaxe do sol e da terra em forma de laranja (LICHTENBERG, 1966, p. 48).

A matemática é uma ciência muito bonita. Mas os matemáticos muitas vezes não valem o diabo. Os matemáticos são quase desnecessários para a Matemática quanto o são para a Teologia. Assim como os homens que se dedicam a esta última, se eles ocupam cargos públicos, pretendem-se possuidores de uma exclusiva santidade e de um relacionamento mais próximo de Deus, de modo que existe entre eles um grande número de vilões autênticos, e os chamados matemáticos, muitas vezes, exigem ser vistos como profundos pensadores, embora seja entre eles que se encontrem as cabeças mais cheias de lixo, incapazes de fazer qualquer tarefa, desde que ela exija 
reflexão e não possa ser reduzida imediatamente àquela fácil combinação de sinais que é obra da rotina, mais que do pensamento (LICHTENBERG, 1966, p. 59-60).

O modo como estamos aqui nos propondo a ver os jogos wittgensteinianos de linguagem - isto é, como encenações simbólicas do corpo humano - pode ser comparado à maneira como, na década de 1930, o artista plástico alemão Hans Bellmer - também leitor e admirador de Lichtenberg - estabelecia relações entre o corpo e a linguagem. De fato, segundo Taylor, Bellmer

sustentava o ponto de vista de que todos os tipos de produção simbólica estão, em última instância, enraizadas na experiência corporal, tais como, por exemplo, aquelas nas quais estão envolvidos gestos, reflexos, sons, palavras, grafismos e objetos. Para ele, figuras de linguagem tais como a hipérbole e a metáfora não pertencem unicamente à literatura, mas também, ao próprio corpo humano, o mesmo ocorrendo com os processos matemáticos que operariam não apenas no domínio abstrato, mas também na carne. Para sugerir que o corpo participa da vida intelectual e que não é a cabeça sozinha que inventa matemática, invocava o aforismo de Lichtenberg de que a nossa convicção sobre a validade de uma equação algébrica reside no cérebro, mas também, em certa medida, no polegar" (TAYLOR, 2000, p. 101-102).

Tal como Lichtenberg e Bellmer o fizeram de modo incidental e não sistemático, também Wittgenstein, com sua devastadora máquina pós-metafísica ${ }^{4}$ de guerra, invadiu o santuário sagrado da Matemática e minou a sua estrutura ao denunciar que ela não poderia operar como uma meta-máquina fundante de si mesma, uma vez que essa suposta metamáquina depende, em última instância, da máquina da linguagem ordinária para poder operar. Ele disse isso assim, no seu costumeiro estilo aforístico:

\footnotetext{
${ }^{4} \mathrm{O}$ prefixo pós em pós-metafísica - o qual será também agregado a outras palavras, resultando em combinações, tais como: pós-estruturalismo, pós-humanismo, pós-ceticismo etc. - não deve ser entendido como negação e nem como uma referência temporal que indicaria "o que vem após", "o que sucede", seja o que seja o antecessor ou o sucessor. Alternativamente, qualquer que seja o problema a que ele esteja referido, usaremos o pós para nos desobrigarmos a optar entre duas alternativas em oposição, ou mesmo entre alternativas intermediárias que expressem graus de intensidade de posicionamento entre essas duas alternativas extremas, reconhecendo, assim, a impossibilidade de superação da oposição, mas abrindo, porém, a possibilidade de se ver de outras maneiras o problema que a oposição captura binariamente. Assim, uma máquina pós-metafísica, embora invista e sempre continue a investir contra a metafísica, ao reconhecer, porém, ser essa luta inglória ou improdutiva, lida não com o problema genérico e abstrato da luta contra a metafísica, mas a luta contra problemas metafísicos em cada uma de suas manifestações contextuais, produzindo-se armas que evitem que deles nos tornemos prisioneiros e dissolvendo-os enquanto problemas, ao mostrar que eles podem ser vistos de outras maneiras, sob outras perspectivas. Esse tipo de estratégia é o que caracteriza, de certo modo, uma atitude terapêutico-gramatical diante de um problema metafísico, quer em suas manifestações no domínio da investigação acadêmica, quer no domínio mais amplo de nossas ações em todos os campos de atividade humana. Trata-se, evidentemente, não de um método genérico que operaria de modo idêntico em todas as situações e a todos os tipos de problemas, mas de uma atitude ético-política - sempre situada e diferenciada - de resistência e luta, e não de acomodação ou resignação. Embora Wittgenstein a tenha empregado em sua luta contra a metafísica no domínio estrito do discurso filosófico, temos nos apropriado dessa atitude no campo da pesquisa em Educação em geral e da Educação Matemática em particular, visando combater todos os tipos de atitudes metódicas cientificistas, de caráter empírico e/ou verificacionistas no âmbito da pesquisa e da ação educativa. Sobre a terapia filosófica wittgensteiniana, consultar (SILVA, 2005); (VILELA, 2010); (HEATON, 2010); (FALCATO, 2012); (MIGUEL, 2012).
} 
[...] Um "problema central da lógica matemática" é para nós um problema da matemática como outro qualquer (WITTGENSTEIN - IF-§ 124).

[...] Se esgotei as justificações, então, atingi a rocha dura e minha pá entortou. Estou então inclinado a dizer: "é assim que eu ajo!" (WITTGENSTEIN, IF-§ 217).

Entretanto, a máquina pós-metafísica de Wittgenstein parece ter incomodado bem mais uma Matemática fundamentalista, estaticamente organizada e vista como um domínio de conhecimento, abalando-a com o propósito de se ressaltar um modo irreverentemente original de se vê-la de outra maneira, isto é, como Matemática em ação, como conjuntos heterogêneos e dinâmicos de encenações simbólicas regradas do corpo humano. Assim, Wittgenstein irá olhar a Matemática bem acomodada no alto de sua torre de marfim e gritar, em linguagem ordinária: "Vem pra vida! Para as diferentes formas de vida!". Ouçamos a sua pauta de reivindicações:

Certamente a matemática é, em certo sentido, uma doutrina - mas também um fazer. (WITTGENSTEIN, 1979, IF- Parte II, p. 219, itálicos do autor).

Se a matemática é um jogo, então, jogar um jogo é fazer matemática, e se assim é, por que dançar não é também matemática? (WITTGENSTEIN, 1998, p. 258); (WITTGENSTEIN, 1987, p. 216).

Por que eu não deveria dizer que o que chamamos de matemática é uma família de atividades em conformidade a uma família de propósitos? (WITTGENSTEIN, 1998, p. 273); (WITTGENSTEIN, 1987, p. 228).

Para Wittgenstein, ver Matemática em encenações corporais é facultativo, mas não é arbitrário. Mas se a Matemática é também um fazer presente na vida cotidiana, seria possível, por exemplo, ver Matemática nos modos como funcionários do mundo dos correios encenam a linguagem para fazer uma carta chegar ao endereço indicado? Podemos significar e distinguir os sinais impressos no envelope com base nas regras gramaticais de dois jogos de linguagem distintos: o da prática cultural da escrita na língua portuguesa e o das práticas culturais de orientação e localização espaciais baseadas no CEP, isto é, no Código de Endereçamento Postal. São essas regras que orientam a significação a ser dada aos sinais impressos no envelope. E são também elas que orientam as performances corporais dos funcionários para que a carta chegue inequivocamente no endereço indicado.

O jogo do CEP está pautado em regras de um sistema decimal diferente daquele que utilizamos na Matemática escolar para registrar e operar com números. O primeiro dígito da esquerda para a direita identifica inequivocamente a região do país, dentre as 10 regiões em que o território brasileiro foi convencionalmente dividido para o caso particular desse jogo. $\mathrm{O}$ dígito seguinte identifica inequivocamente a sub-região, dentre as 10 em que cada região foi convencionalmente dividida. $\mathrm{O}$ terceiro dígito identifica inequivocamente o setor de cada sub- 
região dentre os 10 setores em que cada sub-região foi convencionalmente dividida, e assim por diante. Já os 3 algarismos do sufixo destinam-se à identificação individual de logradouros, códigos especiais e unidades do correio. Temos razões para acreditar que a carta chegará inequivocamente no endereço indicado. Mas isso não significa que ela não possa, por alguma razão, ser extraviada. Mas se isso ocorrer, tenderíamos a investigar as "razões empíricas" do extravio, e não a duvidar das regras gramaticais dos jogos de linguagem. Para Wittgenstein, um extravio da carta em nada comprometeria o caráter inequívoco dessas regras em relação ao propósito social visado. Assim, podemos ver Matemática nas encenações dos funcionários, não porque haja números no envelope, mas porque suas ações são orientadas pelo significado inequívoco que eles devem atribuir ao uso combinado dos sinais gráficos presentes no envelope. Diz Wittgenstein:

[...] é essencial para a matemática que seus signos sejam também usados no civil. É o uso fora da matemática, isto é, é o significado dos signos, aquilo que converte em matemática o jogo de signos (WITTGENSTEIN, 1998, RFM, p. 257, itálicos do autor).

Tenho menos certeza de que este homem tem dores do que de 2 X 2 ser igual a 4 ? É por isso que esta última afirmação seria uma certeza matemática? 'Certeza matemática' não é um conceito psicológico. O gênero de certeza é o gênero do jogo de linguagem (WITTGENSTEIN, 1979, IF - Parte II, p. 216-217, itálicos meus).

Ver Matemática em encenações corporais ordinárias permite desatrelá-la daquela imagem disciplinar exclusivista - escolar ou acadêmica - a que nos acostumamos aprisioná-la. Ajuda-nos a vê-la no plural, como “matemáticas", como aquilo que as pessoas podem fazer, podem aprender a fazer ou fazem sem saber que o fazem quando praticam certos jogos de linguagem. Permite-nos ver a própria Educação Matemática de outra maneira e olhar de forma crítica para o que se tem feito secularmente na escola em nome do que temos chamado "educação matemática escolar". Permite-nos considerar outros inesgotáveis modos como as pessoas se educam matematicamente em todos os contextos de atividade humana. Não seria exagerado dizer que a maior parte de nossa produção de pesquisa em história da Educação Matemática se resume a pesquisas em histórias da Educação Matemática escolar. Para essa produção, a história da Educação Matemática parece começar no século XIX e terminar quando a Matemática deixar de existir como disciplina escolar. 
Passemos, em seguida, a considerar alguns modos como a perspectiva wittgensteiniana, em diálogo 5 com a derridiana, impacta a pesquisa historiográfica em sentido amplo. Ambas partem do pressuposto pós-epistemológico da impossibilidade de existência de conhecimento e de pensamento que sejam anteriores, transcendentes ou independentes de jogos de linguagem, no caso de Wittgenstein, ou de escrituras ${ }^{6}$, no caso de Derrida. Esses modos distintos, porém semelhantemente pós-epistemológicos, de se conceber a linguagem por parte de Derrida e Wittgenstein abrem o campo da pesquisa historiográfica a um conjunto ilimitado de novos objetos e fontes de investigação que sequer chegaram a ser incluídos nas histórias convencionais da Matemática e da Educação Matemática. Deixam de ser vistas como categóricas ou fixas todas as distinções usuais entre objetos e fontes de pesquisa; entre fontes primárias e secundárias; e entre fontes orais, escritas, imagéticas, iconográficas, literárias, ficcionais etc. Todas essas fontes passam a ser vistas como modos diversos de se encenar corporalmente a linguagem.

Um outro impacto é que essas próprias encenações passam a ser vistas como automemorialísticas. Para entender isso, ouçamos Wittgenstein:

\begin{abstract}
Nossa linguagem pode ser considerada como uma velha cidade: uma rede de ruelas e praças, casas novas e velhas, e casas construídas em diferentes épocas; e isto tudo cercado por uma quantidade de novos subúrbios com ruas retas e regulares e com casas uniformes (WITTGENSTEIN, IF-§ 18).
\end{abstract}

Esta analogia entre a linguagem e uma cidade antiga nos permite ver cada encenação da linguagem, ao mesmo tempo, como iterativa e performativa ${ }^{7}$. Iterativa ou repetitiva,

\footnotetext{
${ }^{5}$ Ver possibilidade de diálogo entre essas duas perspectivas não significa uma tentativa de assimilação de uma à outra e nem que esse diálogo seja necessariamente harmonioso ou que não possa se dar sob tensão. O que desejamos é tirar partido dessa tensão provocadora e produtiva de modo a colocar em novos termos o debate acerca do papel da Filosofia na pesquisa historiográfica.

${ }^{6}$ De fato, de acordo com Nigro (2007, p. 182), "pode-se associar a noção de escritura com a de texto, no sentido amplo da desconstrução. [...] No entanto, o que Derrida chama de "texto" quer apontar para todas as estruturas ditas "reais", "econômicas", "históricas", "sócio-institucionais", em suma, todos os referenciais possíveis. É nesse sentido que não há "extra-texto", visto que todo referencial possível é, desde sempre, diferido, cortado pela diferença. Escreve Derrida [no seu Limited Inc]: "todo referencial, toda realidade tem a estrutura de um traço diferencial e só nós podemos reportar a esse real numa experiência interpretativa. Esta só se dá ou só assume sentido num movimento de retorno no diferencial. That's all". Assim, aquilo que chamamos de "realidade" ou de "mundo" somente pode ser acessado através de uma experiência interpretativa, através de uma leitura". Derrida chegou até mesmo a se referir à própria história como "le texte général", sem fronteiras ou limites, com cuja interpretação estaríamos sempre implicados (Cf. CULLER, 1986, p. 130; CULLER, 1998, p. 116).

${ }^{7}$ Ainda que os termos performatividade e iterabilidade não sejam propriamente wittgensteinianos - dado que o primeiro foi cunhado pelo filósofo norte-americano John Austin e o segundo por Derrida, após o debate travado por este filósofo franco-argelino com Searle, discípulo de Austin e com o qual produziu a denominada teoria dos atos de fala, pode-se falar, entretanto, em iterabilidade performativa das encenações da linguagem quer sob perspectivas inspiradas no pensamento de Derrida ou no de Wittgenstein, as quais mantêm entre si semelhanças e dessemelhanças. Embora ambos vejam, respectivamente, as encenações da escritura ou do jogo de linguagem como um compósito heterogêneo de outras encenações precedentes - característica esta a que Derrida denomina iterabilidade -, o conceito de iterabilidade de Derrida é, segundo Mc Donald (2001, p. 30-31), inaceitavelmente estrutural e genérico, uma vez que visto como uma estrutura primordialmente repetitiva de signos que, por não tratar-se de uma repetição empírica, não poderia efetivamente ocorrer. Para este autor, trata-se de um "conceito
} 
porque cada encenação da linguagem mobiliza ou reencena rastros de significados das próprias encenações precedentes da cidade, preservando-lhe, em grande medida, a memória. Mas, as reencenações da linguagem podem também se mostrar performáticas sempre que, ao mobilizarem imprevisíveis rastros de significados de outras encenações, inventam inéditas e surpreendentes composições cênicas da memória da cidade da linguagem.

Assim, a velha cidade que é a nossa linguagem, ela própria, no conjunto de sua materialidade arquitetônica, está sempre sendo reencenada, e o conjunto dessas reencenações simultâneas e heterogêneas itera conservando e performa transformando a paisagem e a memória de toda a cidade ${ }^{8}$.

Um outro impacto é que também as encenações da linguagem orientadas por propósitos narrativos, como todas as outras, passam a ser vistas como modos diferenciados de se encenar corporalmente a linguagem e, ainda que possam ser distinguidos, não podem mais ser desconectados das próprias narrativas que eles encenam. Como não pode haver significação fora de um jogo de linguagem, não faz mais sentido desconectar a "realidade" de um evento da "realidade" de suas encenações pela linguagem, o que não significa negar a ocorrência efetiva do evento, mas destacar que também essa ocorrência efetiva, para ser significativa, não pode ser independente de sua encenação através de um jogo de linguagem. Do mesmo modo, as encenações narrativas posteriores desse evento não são postas em dúvida enquanto eventos culturais distintos entre si e distintos da ocorrência encenada do evento, e todos eles distintamente situados no tempo e no espaço. Até mesmo a nossa "certeza" de distinguir temporalmente e espacialmente essas encenações do evento assume um caráter normativo, uma vez que ela é uma regra que participa da gramática de um jogo de linguagem que constitui culturalmente o nosso modo de falar sobre as noções de tempo e de espaço, do mesmo modo como a distinção que estabelecemos entre as cores só é possível devido à

generalizado de iterabilidade do qual Wittgenstein não poderia compartilhar" pelo fato de a concepção wittgensteiniana de linguagem a ver como heterogênea, o que significa que cada jogo de linguagem é sempre uma linguagem completa e diferente de qualquer outro jogo de linguagem. Por um lado, diz ele, "as práticas de linguagem são performativas, pois elas não meramente transmitem informação ou comunicam significados, mas também performam ações cujo significado depende da possibilidade de ser conectado, através de convenções, com outras ações e eventos" (MC DONALD, 2001, p. 35). Tal método, continua este autor, "também preserva o insight de Derrida de que a linguagem é um processo temporal cujo significado é, ao mesmo tempo, repetitivo e singular, mas que amplia a compreensão de tal temporalidade ao ver a distinção entre as características repetitivas e singulares da linguagem como uma variável contingente sobre atos de iteração produzidos em práticas discursivas particulares" (MC DONALD, 2001, p. 35).

${ }^{8}$ De fato, pensamos que os jogos de linguagem nunca são encenados em um vácuo contextual e/ou com propósitos idênticos, mas sempre em contextos culturais definidos de atividade humana, situados no tempo e no espaço, de modo que, para Wittgenstein, só pode haver concepções situadas de iterabilidade e performatividade. Assim, embora toda encenação da linguagem itere e performe, ela não itera e performa do mesmo modo como outras o fazem. Não existe um padrão estrutural genérico ou específico de iterabilidade performativa que se aplique ou se transfira a todas as encenações da linguagem, sem que haja uma mudança na gramática do jogo, o que significa dizer que todo tipo de iteração da linguagem é sempre uma iteração performática. 
gramática das cores de um de nossos jogos culturais de linguagem. Entretanto, para esse modo pós-epistemológico como tanto Derrida quanto Wittgenstein veem a linguagem, não faz mais sentido distinguir essas encenações do evento com base no critério de atribuição de um estatuto de "ficcionalidade" a umas e o estatuto de "realidade" a outras ${ }^{9}$, ainda que um tal tipo de distinção costume ser feita por concepções hegemônicas de história disseminadas nos mundos acadêmico e escolar. Assim, a Alegoria da batalha de Lepanto, de Veronese, bem como a ilustração de uma batalha de rua entre manifestantes e policiais, costumam ser vistas como narrativas fictícias dessas batalhas. Porém, tanto sob uma perspectiva wittgensteiniana quanto derridiana, tanto as próprias encenações dessas batalhas quanto quaisquer outras que as encenem narrativamente podem ser vistas como encenações corporais da linguagem. E se algumas dessas encenações são vistas como fictícias, não é porque, como se costuma alegar, elas não retratem essas batalhas com fidelidade, ou porque as distorçam ou simplesmente as imaginam, mas porque os modos como Veronese e os ilustradores da Folha encenam narrativamente a linguagem subvertem concepções hegemônicas de história e de narrativa historiográfica $^{10}$.

\footnotetext{
${ }^{9}$ No que se refere a Derrida, o questionamento desta necessidade de distinção parece ser feito com base na atribuição de um estatuto de ficcionalidade a todos os atos de linguagem, neles incluídos o discurso filosófico, as narrativas literárias e as narrativas historiográficas. Esta nossa compreensão baseia-se no diálogo que Haddock Lobo estabelece com o artigo "A literatura é a coisa mais interessante do mundo, talvez mais interessante que o mundo", de Elizabeth Muylaert Duque-Estrada: "O que se entende, então, por uma espécie de estrutura do literário em geral rege-se de acordo com uma lógica do não aparecimento que se define pelo fato de que toda narrativa, todo relato, ficcional ou não, é uma relação com aquilo que ela narra. Nesta relação, tanto o relato, a narrativa, quanto o relatado, o que é narrado, não aparecem em sua presença efetiva. O que Beth herda de Derrida nesta "teoria da literatura" é a constatação de que este não aparecimento estrutural não é exclusividade da literatura, mas de todo relato, constituindo uma espécie de "ficcionalidade constitutiva" de todo discurso (HADDOCK-LOBO, 2011, p. 159 e p. 174, itálicos do autor). Entretanto, penso que, sob um ponto de vista wittgensteiniano, seria inadequado ver esse "não aparecimento", essa "não presença", esse "como se", esse "talvez" - ou o que quer que seja - como um "invariante estrutural" inerente a todas as encenações narrativas da linguagem e que pudesse ser transposto e imputado a todos os demais atos ou jogos de linguagem. Diferentemente desse ponto de vista estrutural, mais adequado seria ver os jogos de linguagem do "como se", do "talvez" ou da "não presença perceptual" como critérios normativos culturalmente eleitos por certas comunidades para se distinguir a presença da não presença perceptualmente detectável, o "real" perceptualmente detectável de um "real" que "estaria de fato lá", ainda que não possa ser perceptualmente detectável, mas nunca de um real perceptual e de um critério normativo de distinção independente de nossos jogos de linguagem.

${ }^{10}$ De acordo com Mc Donald (2001, p. 38), sob uma perspectiva wittgensteiniana, a diferença entre uma narrativa historiográfica e uma narrativa ficcional residiria não em uma suposta possibilidade de distinção categórica entre realidade e ficcionalidade dos eventos que elas mobilizam, mas na subversão performática que as narrativas ficcionais realizam no ato de narrar tais eventos. A ficcionalidade é vista como uma estratégia narrativa performática que subverte o modo causal linear de narrar o evento. Não é um "real em si", isto é, um real agramatical que impede ou deslegitima a "realidade" do ato narrativo ficcional. É a estratégia normativa cultural da ficcionalidade que institui o real de outra maneira, subvertendo modos habituais de narrá-lo. Assim, narrativas ficcionais são vistas como uma série de atos repetitivos que participam, juntamente com as narrativas historiográficas, da formação de concepções de realidade. Nas palavras deste autor, "sob uma perspectiva wittgensteiniana (...) dizer, por um lado, que os eventos retratados em narrativas historiográficas têm um estatuto mais "real" do que os retratados em narrativas ficcionais é apenas dizer que a nossa concepção de história atribui às narrativas historiográficas um tal estatuto. Isto não implica que os eventos históricos sejam "irreais"; em vez disso, como argumenta Hayden White, implica que o poder dos eventos históricos é uma
} 
Penso, entretanto, que a subversão performática não é uma prerrogativa das narrativas ficcionais ou literárias, mas pode também ocorrer em encenações da linguagem em quaisquer contextos de atividade humana, dentre eles, os denominados "científicos". A matéria pode ser vista como se fosse um conjunto de partículas elementares. Conjunto discreto ou contínuo, finito ou infinito? Partículas divisíveis ou indivisíveis? Átomos, prótons, elétrons, quarks, categorias diferentes de quarks .... até onde mais? Não. Podemos ver as coisas de outra maneira. Em vez de partículas materiais adimensionais e indivisíveis, ou divisíveis sem possibilidade de se saber até onde, a matéria pode ser vista como se fosse um conjunto de diferentes filamentos energéticos unidimensionais vibrantes como se fossem as cordas de um violão ... teoria das cordas ou das supercordas.

Desse modo, a abrangência e o poder do discurso ficcional ${ }^{11}$ - do discurso do "como $s e$ " - estão baseados na abrangência e poder das comparações analógicas ou, para usarmos uma expressão wittgensteiniana, das associações por "semelhanças de família" que podemos estabelecer entre dois ou mais jogos de linguagem distintos. Assim, o poder de subversão performática do discurso ficcional reside no poder dos efeitos de analogias discursivas inusitadas e surpreendentes para se lidar com problemas postos em diferentes campos de atividade humana, neles incluídos os campos ditos "teóricos" de investigação acadêmica. Nesse sentido, se podemos "ver Matemática" na encenação corporal da linguagem que faz um carteiro para entregar uma carta, é porque esse modo de vê-la subverte concepções hegemônicas de Matemática, com base na percepção de que a gramática do jogo de linguagem do CEP poderia resolver um problema posto no "mundo dos Correios" se funcionasse como se fosse a gramática do jogo de linguagem do sistema de numeração decimal.

Assim, diante da abrangência e poder indisciplinares do discurso ficcional do modo como o estamos aqui concebendo, penso não ser necessário estabelecer uma linha demarcatória rígida entre narrativas ficcionais e narrativas historiográficas, uma vez que ambas participam igualmente da formação de nossas concepções de realidade e lidam com o

função do papel que as narrativas históricas desempenham em uma cultura, e não da "natureza" dos eventos históricos que os historiadores recontam" (Mc Donald, 2001, p. 38).

11 Segundo Wolfreys, sob um ponto de vista derridiano, dar-se conta da ficcionalidade ou literariedade da escritura é "notar o que já está tomando lugar de outro modo invisivelmente nos efeitos figurais, imaginários, tropológicos, narrativos, simbólicos e, portanto, "citacionais" de toda linguagem. [...] equivale à possibilidade essencial de um "como se" que tem de ser levado em conta. [...] Claramente, existe em funcionamento o pensamento da possibilidade do impossível aqui. Uma ocorrência fantasmática fantasmal é imaginada. A revenance do outro chega. Em sua afirmação, como se articulasse a encenação, a apresentação (Darstellung) em vez da representação (representatio) daquilo que não é nem verdadeiro e nem falso, mas que pode ser concebido, trazido à mente, no que equivale a um tipo de ficcionalidade" (WOLFREYS, 2009, p. 198). 
evento transcorrido como se fosse ... O problema então, se problema há, não consiste em se ver ilegitimidade de qualquer natureza no poder ficcional da linguagem da imaginação e, até mesmo, no poder ficcional da linguagem do delírio, mas em interrogarmo-nos acerca dos efeitos desses poderes e do maior ou menor consentimento que a eles se atribuem em diferentes contextos de atividade humana.

Se nos permitirmos, portanto, investigar a cidade wittgensteiniana da linguagem consentindo também em deixarmo-nos acompanhar por rastros de um olhar fantasmático da "presença ausente" de Derrida, esta "aventura” heterogeneamente compósita não tenderia a ver o historiador como um cientista empírico-verificacionista, vasculhando arquivos nos edifícios judiciários da cidade à busca de documentos comprobatórios da solidez de sua fundação. Também não tenderia a vê-lo como um detetive empírico-indiciário percorrendo ruas, perseguindo pistas e abduzindo rotas para decifrar crimes e enigmas. E nem como um pastor ou cientista hermenêutico, nos templos de todos os tempos espalhados pela cidade, interpretando e elucidando textos para fornecer versões múltiplas - igualmente ou mais ou menos convincentes ou convenientes - de evangelhos e parábolas. Esse historiador poderia se interessar por tudo isso, mas por outras razões ${ }^{12}$.

Esse historiador heterogeneamente compósito poderia ser visto como um terapeuta gramatical-desconstrucionista ${ }^{13}$ que precisa cruzar pontes que estabelecem vínculos entre as

12 Penso ser possível e oportuno desafiar o poder da imagem da história como uma ciência empíricoverificacionista. Segundo Culler, no texto Posições (DERRIDA, 2001, p. 63-64; DERRIDA, 1972, p. 77 e 78 ) o qual consiste em uma entrevista concedida por Derrida a Jean-Louis Houdebine e Guy Scarpetta, em 17 de junho de 1971, o filósofo "destaca a sua desconfiança em relação ao conceito de história com seu sistema de implicações completamente empírico, mas assinala que ele mesmo usa com frequência o termo história de forma crítica, para marcar a sua força. Derrida usa a história contra a filosofia: quando se enfrenta as teorias idealistas e essencialistas, e com defesas da compreensão ahistórica ou transhistórica, afirma a historicidade desses discursos e premissas teóricas. Mas também usa a filosofia contra a história e as pretensões das narrativas históricas. A desconstrução compatibiliza uma crítica filosófica da história e da compreensão histórica com a especificação de que o discurso é histórico e o significado está determinado historicamente tanto na teoria quanto na prática" (CULLER, 1998, p. 116).

${ }^{13}$ Com base em Culler, oferecemos um esclarecimento para o consentimento da constituição desse historiador terapeuta com base na manutenção de uma conexão tensional possível entre um olhar historiográfico desconstrucionista, que se desloca no eixo da indecidibilidade ou da indeterminação do significado, e um olhar historiográfico gramatical, que se desloca no eixo do sentido/sem sentido - isto é, da prevenção contra as armadilhas a que nos remetem os "maus" usos da linguagem: [É esta] "a nossa primeira fórmula: "o significado está determinado pelo contexto, mas o contexto é indeterminável”. [...] o contexto não oferece nunca determinações completas do significado. Contra qualquer conjunto de formulações cabe imaginar novas possibilidades de contexto, incluindo a expansão do contexto produzida pela re-inscrição de sua descrição dentro de um contexto. Esta explicação do significado e do contexto pode aclarar o tratamento que faz a desconstrução do conceito de história, que segue sendo para muitos uma questão pouco clara. Aqueles que falam da história, se referem a ela enquanto base que determina o significado e, posto que Derrida não a utiliza desse modo, costumase vê-lo como "textualista" que nega que os contextos históricos determinam o significado. Mas em sua crítica da filosofia e de outras teorias essencialistas, a desconstrução enfatiza que o discurso, o significado e a leitura são completamente históricos e se produzem em processos de contextualização, descontextualização e recontextualização". [...] Os que defendem uma "aproximação histórica" ou repreendem a desconstrução por refutar o valor da determinação histórica do significado oferecem uma alternativa duvidosa. Uma "aproximação 


\section{diferentes camadas geológico-arquitetônicas da cidade da linguagem. Porém,} inexplicavelmente, uma densa névoa de casualidade, imprevisibilidade e indecidibilidade nublou toda a cidade e as suas pontes não param de se replicar desordenadamente, desorientando o fluxo linear das temporalidades sobrepostas de seus edifícios. Eis o dilema da névoa na voz de Wittgenstein ${ }^{14}$ :

Você deve atentar-se para o fato de que um jogo de linguagem é, por assim dizer, imprevisível. Quero dizer: não se baseia em fundamentos. Não é racional (ou irracional) (WITTGENSTEIN, 1969, OC-§ 559, p. 73); (WITTGENSTEIN, 1990, SC- $§ 559$, p. 157).

E agora, o dilema da névoa na voz de Derrida $^{15}$ :

histórica" é feita pelas narrativas históricas - as narrações de mudanças no pensar e nos pensamentos ou crenças correspondentes a períodos históricos diferenciáveis - para qualquer controle do significado de obras complexas e ricas excluindo significados possíveis que sejam historicamente inadequados. Essas narrativas históricas são elaboradas com base na interpretação de textos supostamente menos complexos e ambíguos de um período e sua autoridade é indubitavelmente questionável. A história, considerada como realidade última e fonte da verdade, se manifesta em produtos narrativos designados para submeter o significado sob uma ordenação narrativa" (CULLER, 1998, p. 115-116).

${ }^{14}$ A noção de imprevisibilidade em Wittgenstein deve ser distinguida das noções acerca do caráter dubitável e/ou de indeterminação do significado. O aforismo seguinte, dentre outros, parece sugerir uma concepção normativa estritamente situada, restrita e não generalizável do caráter indubitável de certos jogos de linguagem, o que reforçaria, segundo alguns autores tais como Henry Mc Donald, a filiação de Wittgenstein a perspectivas pós-epistemológicas não radicalmente céticas: "Portanto, para que você seja capaz de executar uma ordem, tem de haver algum fato empírico acerca do qual você não tenha dúvidas. A própria dúvida baseia-se apenas naquilo que não está em dúvida. Mas como um jogo de linguagem é algo que consiste nos processos recorrentes do jogo ao longo do tempo, parece ser impossível dizer, para qualquer caso individual, que tal e tal têm de ser indubitáveis para que haja um jogo de linguagem, mas pode dizer-se que, enquanto regras, alguns juízos empíricos têm de ser indubitáveis" (Wittgenstein, 1969, OC-§ 519, p. 68); (Wittgenstein, 1990, SC-§ 519, p. 147). Segundo Mc Donald (2001, p. 19-20), “Wittgenstein não via os jogos de linguagem como arbitrários porque os modos como eles operam ou funcionam não podem ser separados das formas de ação das quais eles emergem". Além disso, continua este autor, "os jogos de linguagem são vistos como fenômenos determinados por serem eles modelados pela recorrência de convenções discursivas e não discursivas enraizadas em formas de vida que não são necessariamente governadas por regras". É nesse sentido que se poderia, então, dizer que os jogos de linguagem são fenômenos determinados, não arbitrários, mas também, imprevisíveis. E seriam imprevisíveis "não porque as regras não sejam importantes para as suas performances", mas porque "não pode haver regra para a aplicação de uma regra". Isso porque "não pode haver qualquer meta-regra, fundada em uma estrutura kantiana da consciência, que escape às deformações de significado produzidas pela sua aplicação. Além disso, o funcionamento da linguagem obedece a uma lógica que não pode ser logicamente explicada, porque ela fornece os canais ao longo dos quais fluem o sentido e o sem sentido, a razão e o pensamento. Isso significa que os jogos de linguagem não são definidos por suas regras. O que se conta como "vitória" ou "derrota" em qualquer jogo não constitui uma propriedade comum a todos os jogos, mas uma função da aplicação de suas regras em casos particulares para os quais não há regras. Os jogos de linguagem não possuem nem fundamento epistemológico e nem ontológico. Eles não têm nada em comum entre si, nem mesmo a propriedade de "existência".

${ }^{15}$ Pensamos que a noção wittgensteiniana de imprevisibilidade da gramática, isto é, das regras constitutivas de um jogo de linguagem, no sentido de determinação da significação, da orientação e da tomada de decisões na encenação de um jogo de linguagem em casos particulares e situados, ainda que não possa ser assimilada à noção derridiana acerca do caráter indecidível da escritura, mantêm com ela estreitas semelhanças de família a ponto de gerar controvérsias entre os comentadores tanto da obra de Derrida quanto da de Wittgenstein. Essa discussão tópica - mas que está enredada em outras polêmicas afins em torno da determinação, indeterminação do significado e do caráter regrado, arbitrário, dubitável ou inequívoco da significação - tem gerado controvérsias entre leituras mais ou menos céticas tanto de Wittgenstein quanto de Derrida. Jonathan Culler, por exemplo, rebate do seguinte modo uma argumentação anticética típica de certos críticos do movimento desconstrucionista, baseada em leituras não céticas da obra de Wittgenstein: [Alguns críticos da desconstrução afirmam que] "digam 
Para melhor analisar esse afastamento [...] foi preciso analisar no texto da história da filosofia tanto quanto no texto dito "literário" certas marcas do que chamei de "indecidíveis", isto é, unidades de simulacro, "falsas" propriedades verbais, nominais ou semânticas, que não se deixam mais compreender na oposição filosófica (binária) e que, entretanto, habitam-na, opõem-lhe resistência, desorganizam-na, mas, sem nunca constituir um terceiro termo, sem nunca dar lugar a uma solução na forma da dialética especulativa (o pharmakon). [O indecidível] não é nem o remédio nem o veneno, nem o bem nem o mal, nem o dentro nem o fora, nem a fala nem a escrita; o suplemento não é nem um mais nem um menos, nem um fora nem um complemento de um dentro, nem um acidente nem uma essência etc. [...]. Nem/nem quer dizer ou "ao mesmo tempo" ou "ou um ou outro" (DERRIDA, 2001, p. 49-50).

Desse modo, o historiador terapeuta gramatical-desconstrucionista está impedido de atravessar as pontes da cidade da linguagem, apenas munido da confiança dogmática em lógicas dedutivas, indutivas, abdutivas, ou quaisquer outras, porque, para ele, elas não têm o poder de dissipar a névoa ${ }^{16}$. E mesmo quando conseguem iluminar parte da cidade, só o fazem ao preço de lançar as outras em zonas sombrias de profundo esquecimento ${ }^{17}$ :

o que digam os filósofos, temos experiências de determinação e captação de significados, mas em seguida, tratam essa experiência como se fosse uma base sólida para a refutação do ceticismo. Admiradores [de Wittgenstein] falam como se o jogo de linguagem fosse em si mesmo uma base - verdadeira presença que determinasse o significado. Mas quando se intenciona expressar este argumento apresentando as regras e as convenções do jogo de linguagem, encontramo-nos com todos os problemas que temos discutido. Um seguidor de Derrida estaria de acordo com o fato de que a linguagem é um jogo, mas pode seguir com o problema de que nunca se pode estar de todo seguro de quem joga, ou se joga "seriamente", ou de quais seriam as suas regras, ou ainda, de qual seria o jogo. E esta incerteza não é incidental ou externa. Aqueles que citam Wittgenstein tendem a argumentar que o jogo de linguagem e suas regras simplesmente estão dados. "É simplesmente um fato". Afirma-se que Wittgenstein disse "que as pessoas estabeleceram tais e tais regras". É sempre possível, contudo, que uma nova descrição altere as regras ou situe uma emissão em um jogo de linguagem diferente. Ao comentar uma frase que aparece entre aspas em Nachlass de Nietzsche: "Eu esqueci meu guarda-chuva", Derrida escreve "mil possibilidades permanecem abertas". Permanecem abertas não porque o leitor possa fazer que a frase signifique qualquer coisa, mas porque cabe sempre realizar outras especificações contextuais ou interpretações do "texto global" [da história]. Como deveria estar claro, a desconstrução não é uma teoria que defina o significado para dizermos como encontrá-lo" (CULLER, 1998, p. 117-118).

${ }^{16}$ Tentando "dissipar a névoa" ou, pelo menos, torná-la menos densa, Nigro censura e faz reparos esclarecedores em relação a leituras radicalmente céticas de Derrida: "Na Gramatologia, Derrida utiliza-se com frequência do termo "jogo", que tende a desaparecer dos textos posteriores, talvez pela associação errônea entre a escritura (écriture) e a noção de "free play" com a qual a desconstrução foi associada, sobretudo nos Estados Unidos. Mas Derrida nunca falou em "jogo livre" da desconstrução, como se a impossibilidade da "realização pura da presença em si" implicasse necessariamente no relativismo e/ou irracionalismo. O que Derrida afirma é que "a escritura é o jogo na linguagem" e que esse jogo deve ser pensado como ausência de significado transcendental. De modo talvez menos contextualista que Wittgenstein, o jogo da escritura não é um tipo de "jogo de linguagem" wittgensteiniano. O que Derrida nos propõe pensar é o jogo em geral que tem lugar na linguagem ou, em suas palavras: "é preciso pensar primeiramente o jogo do mundo antes de tentar compreender todas as formas de jogo no mundo" (NIGRO, 2007, p. 154).

${ }^{17}$ Segundo Mc Donald $(2001$, p. 35), a concepção derridiana de escritura, além de ver a linguagem em sua generalidade abstrata, já a pressupõe fendida em uma parte repetível ou iterável e outra performativa, isto é, singular ou idiossincrática. Além disso, tal fenda ou rachadura, além de ser vista por Derrida como uma propriedade inerente à linguagem em geral, seria também responsável por gerar o que ele mesmo chama de indecidibilidade, a qual, por sua vez, gera uma indeterminação do significado. Vimos que, para Wittgenstein, a linguagem é uma forma de ação. Mc Donald, ressalta, entretanto, que ele vê essa ação "não tanto como intencional e regrada, mas como potencialmente singular ou envolvida em contextos de atividades repetitivas que não são logicamente fundamentadas e, portanto, imprevisíveis em termos de possibilidades de significação" (MC DONALD, 2001, p. 35). Ainda para este autor, embora Wittgenstein compartilhe com Derrida a concepção dos atos de linguagem ao mesmo tempo como repetitivos e singulares, diferentemente de Derrida, "ele não 
"Recordo-me de que naquela ocasião teria permanecido com prazer por mais tempo". - Que imagem desse desejo surgiu em minha alma? Nenhuma. O que vejo na minha lembrança não autoriza nenhuma conclusão sobre meus sentimentos. E, no entanto, recordo-me claramente de que eles existiam (Wittgenstein - IF-§ 651).

Diante da situação contraditória gerada pela recusa a se atribuir poder inferencial a algo que nos acostumamos a chamar de memória, mente ou $\mathrm{eu}^{18}$, Wittgenstein transfere o

coloca essa repetitividade e singularidade em oposição uma com a outra; em vez disso, as relações que entre elas subsistem são de modulação e diferencialidade, cuja incerteza de significação emerge do caráter decidível, porém limitado, das descrições. Trata-se de uma incerteza que, tal como para Bohr e Heisenberg, está indissociavelmente atachada às ferramentas de medida, e não a uma indecidibilidade intrínseca em que a inexplicabilidade do significado decorreria de uma diferença originária de caráter ontológico ou pré-ontológico. Assim, para Wittgenstein, as práticas de linguagem são iterativas mais do que iteráveis, como o são para Derrida. Para Wittgenstein, as lógicas das práticas da linguagem não se restringem a uma forma de oposição binária, mas permite gradações de diferenças de significação, o que Wittgenstein, como também o faz Bourdieu, chama de diferentes "ritmos" e "tempos" dos jogos de linguagem e das formas de vida" (MC DONALD, 2001, p. 30-31). Esse comentário de Mc Donald é importante porque nos sugere uma concepção wittgensteiniana de iterabilidade performática que, devido ao seu caráter pós-epistemológico e pós-ontológico, desloca o olhar de um suposto outro superior ou superante que poderia ser visto a partir do que se vê, para múltiplos outros que passam a ser vistos a partir de modos distintos de se ver o mesmo. A seguinte passagem do Cultura e valor sugere fortemente essa concepção: "Cada uma das frases que escrevo procura exprimir tudo, isto é, a mesma coisa repetidas vezes; é como se elas fossem simplesmente visões de um mesmo objeto, obtidas de ângulos diferentes. Poderia dizer: se o lugar que pretendo chegar só se pudesse alcançar por meio de uma escada, desistiria de tentar chegar lá. Pois o lugar a que de fato tenho de chegar é um lugar em que já me devo encontrar. Tudo aquilo que se pode alcançar com uma escada não me interessa" (WITTGENSTEIN, 2000, p. 21).

${ }^{18}$ Segundo Mc Donald (2001, p. 19, nota 35), Wittgenstein contrasta os fenômenos espaçotemporais com aquilo que ocorre no mundo do pensamento. Como decorrência desse contraste, um outro também se estabelece, qual seja, entre símbolo expressivo e pensamento expresso. Mais ainda, com base no ponto de vista wittgensteiniano de que os jogos de linguagem são formas de ação, o pensamento não é visto como uma atividade mental. Já para Derrida, como assinala Nigro (2007, p. 150-151), "o funcionamento do 'Eu' é tão iterável quanto outra palavra qualquer, o que impede a compreensão plena do sentido da frase, isto é, da intenção completa e originária daquele que diz 'eu'. [...] Para a desconstrução, o 'eu' revela a originalidade própria à linguagem, qual seja, a de poder funcionar independentemente do querer-dizer do falante que diz 'eu'". Desse modo, pensamos que, tanto para a perspectiva wittgensteiniana quanto para a derridiana, ainda que a linguagem possa ser privadamente praticada, não existem jogos originariamente privados de linguagem e, portanto, não podem haver sujeitos ou formas de subjetividade que se constituam independentemente de modos públicos e compartilhados de se encenar a linguagem. Com base nesse enunciado gramatical simultaneamente wittgensteiniano e derridiano, uma prática terapêutico-desconstrucionista no domínio historiográfico levaria o historiador a assumir sem hesitação a ficcionalidade/espectralidade atual e tópica de todos os autores-personagens que participam de suas encenações da linguagem. Isso porque, quando o historiador assume a encenação terapêutica como uma atitude metódicoconceptual de investigação historiográfica, deve estar ciente de que sempre dialoga com espectros de sujeitos e de jogos de linguagem, e nunca com supostos sujeitos e práticas autônomos, isto é, independentes da linguagem. $\mathrm{O}$ historiador deve estar também ciente de algo ainda mais radical: que ele sempre dialoga com espectros de sujeitos e de práticas, mesmo quando interage com quem quer que seja em encenações presenciais. Isso porque, do mesmo modo como só podemos interagir significativamente com o mundo da natureza e seus fenômenos através de ações corporais orientadas por gramáticas de diferentes jogos de linguagem, o mesmo ocorre quando significamos o outro humano e a nós próprios, bem como as interações - presenciais ou não - que estabelecemos uns com os outros. De certo modo, este nosso ponto de vista tem base em ecos tanto do pensamento de Derrida quanto do de Wittgenstein. Segundo Haddock-lobo (2011, p. 157), "na Farmácia, quando Derrida diz que a escritura é desde sempre encenação, o autor está antecipando uma discussão central em sua obra, qual seja, a da relação entre filosofia e ficção, tornando transparente o que seria a "ficcionalidade da língua", de todo discurso e, portanto, da escritura". Já nas Investigações, o seguinte aforismo de Wittgenstein soa sugestivo a esse respeito: "E fazemos aqui o que fazemos em mil casos semelhantes: porque não podemos indicar uma ação corporal que chamamos de apontar para a forma (em oposição, por exemplo, à cor), então dizemos que corresponde a essas palavras uma atividade espiritual. Lá onde nossa linguagem nos faz supor um corpo, e não há corpo algum, ali gostaríamos de dizer, existe um espírito" (WITTGENSTEIN, IF- 36, itálicos do autor). 


\title{
problema das conexões inferenciais ${ }^{19}$ entre as pontes que ligam o presente ao passado ao
}

\author{
domínio das encenações cotidianas da linguagem, dizendo assim:
}

O fato fundamental aqui é que fixamos regras para um jogo e que quando as seguimos, as coisas não se passam como havíamos suposto. Que, portanto, nos aprisionamos em nossas próprias regras. Este aprisionamento em nossas regras é o que queremos compreender. A posição cotidiana da contradição ou sua posição no mundo cotidiano: este é o problema filosófico (WITTGENSTEIN - IF-§ 125).

Não se trata da elucidação de um jogo de linguagem pelas nossas vivências, mas da constatação de um jogo de linguagem. [...] Pois o que está oculto não nos interessa (WITTGENSTEIN-IF-§ 655, itálicos meus) e (WITTGENSTEIN - IF-§ 126).

\section{O historiador terapeuta deve, então, confiar apenas na constatação das rachaduras e} fendas expostas nas superfícies das paredes dos presídios obscuros da cidade da linguagem ${ }^{20}$.

\footnotetext{
${ }^{19}$ O problema de estabelecimento de conexões inferenciais na prática terapêutico-desconstrucionista no domínio historiográfico é sutil, delicado e complexo. Não há regras ou quaisquer prescrições metódicas gerais ou situadas que possam orientar essa prática. Entretanto, no que diz respeito ao aspecto mais propriamente gramatical ou wittgensteiniano de uma prática terapêutica, temos falado em uma certa "atitude metódico-conceptual" que tende a constituir e a lidar com o corpus de uma investigação historiográfica com base no acionamento de uma "lógica" de dispersão metonímica da significação (MC DONALD, 1994), que consiste em estabelecer e percorrer, de um modo livremente exploratório, possíveis, mas não arbitrárias conexões semântico-sensíveis no que está efetivamente manifesto em jogos de linguagem publicamente acessáveis, de narradores presenciais ou remotos, eleitos, pelo historiador terapeuta, a se envolverem com o problema sob investigação. Já o aspecto mais propriamente desconstrucionista ou derridiano de uma prática terapêutica estaria centralmente baseado na crença na iterabilidade do eu em diferentes inscrições contextuais da linguagem, ponto de vista este que levaria o historiador a lidar com o corpus de sua investigação com base no acionamento de uma "lógica" da espectralidade (WOLFREYS, 2007) que se poria nos rastros de rastros de significação de espectros presentes em suas ausências, mas que deixam rastros que se manifestam nos textos ou escrituras do corpus. Com base neste nosso modo de se falar em e de se praticar a terapia gramatical-desconstrucionista, acreditamos poder acusar uma certa analogia nos modos de agir do historiador wittgensteiniano terapeuta gramatical e do historiador derridiano desconstrucionista. Também Nigro acredita poder aproximar, de certo modo, o pensamento derridiano do wittgensteiniano, quando expressa a convicção de que "apesar de Derrida não fazer referência explícita ao trabalho de Wittgenstein, a noção de ‘jogo de linguagem' desenvolvida nas Investigações Filosóficas pode contribuir para pensar a écriture derridiana e os demais 'quase-conceitos' que lhe são correlatos, como différance, iterabilidade e disseminação" (NIGRO, 2007, p. 152). Um exemplo deste nosso modo de praticar uma terapia desconstrucionista pode ser acessado na referência (MIGUEL, 2012).

${ }^{20}$ Dizer que uma atitude metódico-gramatical inspirada na terapia wittgensteiniana deve partir do que está manifesto nas encenações da linguagem não significa que ela deva se limitar ao que está manifesto nessas encenações. Ela pode e necessita praticar a interdiscursividade e os deslocamentos semântico-sensíveis, não para revelar o que estaria supostamente oculto nas encenações terapêuticas da linguagem, mas para desconstruir, isto é, descompactar enunciados nelas manifestos, mostrando-nos que é possível vê-los ou compactá-los de outras maneiras. Assim, uma terapia wittgensteiniana, pelo menos tal como temos procurado praticá-la, não se resume a percursos sem rumo de usos de palavras, de enunciados ou do que quer que seja em diferentes jogos de linguagem, e nem a um acúmulo pluralista e polissêmico correspondente de significações igualmente sustentáveis que coexistiriam pacificamente, mas sim, a seguir percursos orientados visando à desconstrução de enunciados metafísicos, absolutistas e essencialistas manifestos nas encenações da linguagem. Nesse sentido, como destaca Salles, a terapia é uma atitude metódica negativa que opera idiossincraticamente em função de cada problema particular a ser desconstruído: "Na descrição da terapia, é difícil ocultar um certo sentimento de conspiração contra as origens, de método que se anula. Essa negatividade do labor filosófico não é gratuita. Afinal, o filósofo não deixa de dirigir-se a questões que, sem sua ação, talvez jamais fossem colocadas. Opera como que pelo inusitado. Assim, amealha exemplos, como uma velha senhora guardaria farrapos, botões, peças soltas. Não obstante, sempre o faz com um propósito determinado, mas de tal sorte que sua ação pode ela própria ser o maior sintoma da doença que procura tratar, assemelhando-se o procedimento terapêutico e a doença: "Em certo sentido, a recolha de exemplos é boa; em outro, porém, é o mais seguro sinal da doença filosófica". Por isso também, repete várias vezes Wittgenstein, o filósofo só pode tratar uma questão como uma doença, não
} 
São elas os rastros de significados que podem atenuar a névoa e dar visibilidade parcial às pontes que conectam as ruínas da cidade antiga aos edifícios reparados da nova cidade. Wittgenstein parece dizer isso assim:

[...] Pode-se chamar de "filosofia" o que é possível antes de todas as novas descobertas e invenções ${ }^{21}$ (Wittgenstein - IF-§ 126).

Assim, a atitude metódica que orienta o historiador terapeuta é a desconstrução ${ }^{22}$, isto é, a descompactação - por constatação e descrição - dos tipos de enxertos utilizados em

podendo mais haver exatamente um método, mas sim métodos, ou melhor, diferentes terapias" (SILVA, 2005, p. 90-91).

${ }^{21}$ Pensamos que este "consolo" aforístico pós-cético, que só teria o poder de atenuar a névoa e dar visibilidade parcial à cidade da linguagem, parece retirar do discurso filosófico qualquer pretensão de efetividade positiva e investi-lo de um poder meramente especulativo, que não deixa, porém, de ser performativo. Mas esse poder performativo, não podendo ser positivamente efetivo, opera efetivamente de um modo negativo, isto é, operar para desfazer confusões e equívocos conceituais ou para dissolver problemas agramaticais, isto é, problemas inacessíveis aos poderes de gramaticalização da linguagem. Assim, os jogos filosóficos de linguagem operam terapeuticamente "como se" de fato houvesse problemas filosóficos a serem resolvidos. É essa potência terapêutico-performativa negativa que, a nosso ver, caracterizaria a ficcionalidade derridiana dos jogos filosóficos de linguagem. Já a ficcionalidade positiva de outros jogos de linguagem (disciplinarizados ou não, tidos ou não como "científicos") se caracterizaria no sentido de colocarem e lidarem com problemas que, mesmo se indeterminados ou indecidíveis, se mostrem gramaticalizáveis. Assim, pensamos que conceber a filosofia como o discurso que "antecede toda nova descoberta", como o faz Wittgenstein, em vez de apontar para uma distinção rígida entre discursos científicos e não científicos, sugere uma distinção não rígida - bem mais ampla e indisciplinar - entre jogos de linguagem performático-ficcionais positivos e jogos de linguagem performáticoficcionais negativos. Desse modo, uma advertência que uma perspectiva terapêutica da história faria ao historiador, como, de resto, a todo pesquisador, não diz respeito ao "falso" dilema acerca do quão o seu discurso se afasta da ficcionalidade ou se aproxima da "realidade" ou da "verdade", mas sim, à natureza mais ou menos gramaticalizável do problema submetido à investigação. Entretanto, o problema crucial maior é que nunca conseguimos ter, a priori - isto é, sem submeter o problema sob investigação à própria prática terapêutica -, a certeza ou a clareza suficiente acerca de seu potencial de gramaticalização, e nem a posteriori - isto é, após julgarmos terminada a investigação -, se a gramática que a orientou o fez adequadamente. A nossa linguagem só nos dá o poder de atenuar a névoa, mas nunca o de dissipá-la por completo. É por isso que, sob uma perspectiva wittgensteiniana, todo problema é passível de ser terapeuticamente abordado, ainda que, nem sempre, essa opção se mostre conveniente, produtiva ou mesmo desejável. É por essa razão também que não se pode decretar o fim da filosofia, isto é, do discurso especulativo, metafísico e dogmático. A necessária luta terapêutica contra o discurso metafísico não pode ser feita sem ele, de modo que a própria prática terapêutica se mostra uma especulação metafisicamente "doentia” acerca da própria "doença” que intenciona erradicar. É esse o seu caráter ficcional: ela precisa lidar com um jogo agramatical de linguagem "como se" ele fosse gramaticalizável, de modo que, para Wittgenstein, "a terapia nunca deixa de ser autoterapia" (SILVA, 2005, p. 92). Nas palavras do próprio Wittgenstein essa ficcionalidade é dita assim: "A filosofia desata os nós em nosso pensamento, que urdimos de modo insensato; por isso, porém, ela precisa fazer movimentos tão complicados quanto o são esses nós. Embora então o resultado da filosofia seja simples, não o pode ser seu método de chegar a ele. A complexidade da filosofia não está na sua matéria, senão em nosso entendimento atado" (WITTGENSTEIN, Observações Filosóficas, § 2).

${ }^{22}$ Richard Rorty (s/d, p. 2), por exemplo, divide os wittgensteinianos em dois grupos por ele denominados de "terapeutas" e "pragmáticos", situando-se, ele próprio, entre os últimos. Segundo este filósofo, o principal ponto de divergência entre esses dois grupos seria o de que os pragmáticos tenderiam a não dar importância à explícita recusa de Wittgenstein em propor teorias filosóficas alternativas a problemas, após tê-los desconstruído mediante terapias gramaticais locais. Assim, contrariando a atitude anti-teórica do próprio Wittgenstein, os pragmáticos tenderiam a ver positivamente o tratamento terapêutico wittgensteiniano como um método filosófico legítimo, desde que se pudesse "retificá-lo" com a permissão de substituição de uma má teoria sobre o problema levado à terapia por uma teoria melhor. Já os "wittgensteinianos terapeutas", segundo Rorty, mais fiéis ao ponto de vista anti-teorizante de Wittgenstein, sustentariam que o papel do filósofo seria o de meramente envolver-se em uma atividade terapêutica de elucidação gramatical de caráter desconstrucionista, jamais se permitindo propor teses ou sustentar teorias. Esse desacordo aparentemente insignificante parece, entretanto, remeter a um 
diferentes reencenações narrativas dessas rachaduras e fendas, nos contextos dos presídios que essas próprias reencenações construíram para si mesmas. O propósito visado pela investigação historiográfica é o de descrever como e com base em que estratégias e recursos retóricos, argumentativos, imagéticos, cênicos, literários ou ficcionais esses enxertos produzem seus efeitos performáticos, isto é, como performam as suas próprias dissonâncias e contradições, as transgressões de regras de suas próprias gramáticas, os seus agramaticais, o sem sentido ${ }^{23}$. O historiador terapeuta jamais se esquece da máxima derridiana de que "toda tese é uma prótese ${ }^{, 24}$. E nem do aforismo wittgensteiniano que inspirou esta nossa encenação terapêutica da linguagem:

desentendimento mais amplo acerca dos usos da própria palavra "filosofia". De fato, para Rorty (s/d, p. 6), "filosofia", nas seções metafilosóficas das Investigações de Wittgenstein, significaria algo como "discussões causadas pelo mau uso da linguagem", concepção esta considerada inadmissível para os pragmáticos, dado que explicar o "sem sentido" das discussões filosóficas pelo argumento do mau uso da linguagem implicaria, para eles, em "explicar o absurdo por algo ainda mais absurdo" (Rorty, s/d, p. 6). Penso, entretanto, que o modo como Wittgenstein pratica a sua terapia nas Investigações, por visar, em última instância, guerrear contra a metafísica no próprio terreno da metafísica, o leva, muitas vezes, a se envolver com jogos metafilosóficos de linguagem com o único propósito de pô-los em questão, de deslegitimá-los. A sua máquina discursiva de guerra não tem o poder de analisar-se a si própria, isto é, não tem o poder de elucidar as próprias regras segundo a qual opera. Ela não pode operar como uma meta-máquina de si mesma. Esta seria a pretensão do discurso metafísico praticado pela filosofia.

${ }^{23}$ Orientado por uma atitude que ele próprio denomina de "hipercética", na leitura que Haddock-Lobo faz do texto Acts of Literature de Derrida, ele defende que "a lucidez filosófica, a tarefa rigorosa do filósofo consiste então em nada mais do que aceitar e suportar o estatuto ficcional de seu discurso, a impossibilidade radical de se alcançar qualquer coisa que se aproxime de um estatuto de verdade [...]. O fato é que a estrutura mesma deste "isto" que se quer alcançar é sua indizibilidade [...]." (HADDOCK-LOBO, 2011, p. 174). Uma diferença entre esta forma de hiperceticismo manifesta por Haddock-Lobo e uma atitude pós-cética que, a nosso ver, poderia orientar a prática terapêutico-desconstrucionista no domínio historiográfico - e que pensamos ser mais condizente ao modo como o próprio Wittgenstein a pratica com o propósito de desconstruir o discurso (filosófico) metafísico - é que ela não necessita ver essa "ficcionalidade constitutiva de todo discurso" nos termos de uma concepção de verdade que insiste em "medir" a efetividade do ficcional com base no critério de sua aproximação assintótica quer de uma suposta "realidade internamente estruturada", independente do dizível do discurso, quer de um suposto "indizível estrutural" que se oculta por trás do que se julga poder ser dito. Uma proposta de tradução para o inglês de um aforismo de Wittgenstein diz isso de uma maneira simples e concisa: "It is easy to imagine a language consisting only of orders and reports in battle. [...] And to imagine a language means to imagine a form of life" (Wittgenstein, PI - § 19, p. 11, 2009 , itálicos nossos). Já em uma proposta de tradução desse mesmo aforismo para o português, ele fica assim: "Pode-se facilmente representar uma linguagem que consiste apenas de comandos e informações durante uma batalha. [...] E representar uma linguagem significa representar-se uma forma de vida" (Wittgenstein, 1979, IF- § 19). Como se nota, o verbo "to imagine" em inglês, eleito por Anscombe e Hacker para traduzir o verbo alemão "vorstellen", pode significar tanto "imaginar", como "representar-se", isto é, "representar para si mesmo", opção esta eleita por José Carlos Bruni para traduzir este mesmo verbo alemão para o português. Assim, para Wittgenstein, é somente imaginando, representando ou encenando corporalmente uma linguagem, isto é, uma forma pública e cultural de vida, que podemos dizer o mundo, as formas de vida humana ou não humana e dizermo-nos a nós próprios enquanto humanos, ponto de vista este que nos remete a uma concepção de ficção tanto como presença quanto como ausência do representante e do representado. Desse modo, sob uma concepção pós-cética, a ficcionalidade constitutiva do jogo de linguagem wittgensteiniano transforma - por incorporação situada e não generalizável - o indecidível nem/nem constitutivo da ficcionalidade derridiana em uma "certeza" vista como confiança cultural anômica, imprevisível e sem fundamento tanto de uma presença na ausência quanto de uma ausência na presença.

${ }^{24}$ Derrida dizia que "toda tese é uma prótese", chegando mesmo a sugerir a produção de um tratado sobre enxertia textual que seria escrito com base no estabelecimento de analogias entre diferentes tipos de enxertias textuais, vegetais e animais. Segundo Jonathan Culler (1997, p. 155), tal tratado "trataria o discurso como o 
Uma imagem nos mantinha presos. E não pudemos dela sair, pois ela residia em nossa linguagem, que parecia apenas repeti-la para nós inexoravelmente (Wittgenstein - IF-§ 115).

\section{Referências}

CULLER, J. On deconstruction: theory and criticism after structuralism. New York: Cornell University Press, 1986.

CULLER, J. Sobre la deconstrucción: teoría y crítica después del etructuralismo. Marid: Ediciones Cátedra, 1998.

DERRIDA, J. Positions. Paris: Les éditions de Minuit, 1972.

DERRIDA, J. Posições. Belo Horizonte: Autêntica, 2001.

FALCATO, A. C. S. A filosofia como terapia gramatical segundo Wittgenstein. Covilhã: LusoSofia: press, 2012.

FOLHA DE SÃO PAULO. Jornal de circulação diária. São Paulo; 15 de junho de 2013.

GLOCK, H. J. Dicionário de Wittgenstein. Rio de Janeiro: Zahar, 1998.

HADDOCK-LOBO, R. Para um pensamento únido: a filosofia a partir de Jacques Derrida. Rio de Janeiro : Nau: Ed. PUC-Rio, 2011.

HEATON, J. M. The Talking Cure: Wittgenstein's Therapeutic Method for Psychotherapy. UK: Palgrave Macmillan, 2010.

LICHTENBERG, G. C. Aphorismes. Préface de André Breton. Introduction e traduction de Marthe Robert. Hollande: Éditeur Jean Jacques Pauver, 1966.

MCDONALD, H. Wittgenstein, Narrative Theory, and Cultural Studies. Telos: Critical Theory of Contemporary, n. 121, p. 11-53, New York, 2001.

MCDONALD, H. The narrative act: Wittgenstein and narratology. Telos: Critical Theory of Contemporary, New York, v. 4, 1994. Acesso online:

http://www.pum.umontreal.ca/revues/surfaces/vol4/mcdonald.html

MIGUEL, A. Infâncias e pós-colonialismo. Educação \& Sociedade, Campinas,v. 35, n. 128, p. 857879, jul./set. 2014.

MIGUEL, A. Vidas de professores de matemática: o doce e o dócil do adoecimento. In: TEIXEIRA, I. A. C; PAULA, M. J; GOMES, M. L. M; AUAREK, W. A. (Org.) Viver e Contar: experiências e práticas de professores de Matemática. São Paulo: Editora Livraria da Física, 2012, p. 271-309.

MIGUEL, A.; VILELA, D. S.; MOURA, A. R. L. Problematização indisciplinar de uma prática cultural numa perspectiva wittgensteiniana. Revista Reflexão e Ação, Santa Cruz do Sul, v. 20, n. 2, p. 1-26, jun./dez. 2012 b.

produto de vários tipos de combinações ou inserções. Explorando a iterabilidade da língua, sua capacidade de funcionar em novos contextos com nova força, um tratado de enxertia textual tentaria classificar vários modos de inserir um discurso em outro ou de intervir no discurso que se está interpretando". 
MIGUEL, A.; VILELA, D. S.; MOURA, A. R. L. de. Desconstruindo a matemática escolar sob uma perspectiva pós-metafísica de educação. Zetetiké, Campinas, v. 18, p. 129-206, número temático, 2010.

NIGRO, R. B. Desconstrução linguagem política. 2007, 279 páginas. Tese de doutorado. Departamento de Filosofia da PUC-Rio, Rio de Janeiro, 2007.

RORTY, R. Wittgenstein e a virada linguística. Tradução de Paulo Ghiraldelli Jr. CEFA: Centro de Estudos em Filosofia Americana, s/d.

SILVA, J. C. S. P. Filosofia e terapia em Wittgenstein. Analytica, vol. 9, n. 2, p. 88-112, 2005.

STATEN, H. Wittgenstein and Derrida. Lincoln: University of Nebraska Press, 1986.

TAYLOR, S. Hans Bellmer: the anatomy of anxiety. London: The MIT Press, 2000.

VILELA, D. S. A terapia filosófica de Wittgenstein e a educação matemática. Educação e Filosofia, Uberlândia, v. 24, n. 48, p. 435-456, jul./dez. 2010.

WITTGENSTEIN, L. Wittgenstein's lectures on the Foundations of Mathematics. DIAMOND, C. (Ed.). New York: Cornell University Press, 1976.

WITTGENSTEIN, L. Remarks on the foundation of mathematics. VON WRIGHT, G. H.; RHEES, R.; ANSCOMBE, G. E. M. (Ed.). Translated by G. E. M. Anscombe. Oxford: Basil Blackwell, 1998.

WITTGENSTEIN, L. Observaciones sobre los fundamentos de la matemática. Versión de Isidoro Reguera. Madrid: Alianza Editorial, 1987.

WITTGENSTEIN, L. Culture and value. VON WRIGHT, G. H.; NYMAN, H. (Ed.). Oxford (UK): Blackwell Publishers, 1998.

WITTGENSTEIN, L. Cultura e valor. Tradução de Jorge Mendes. Lisboa: Edições 70, 2000.

WITTGENSTEIN, L. On certainty. ANSCOMBE, G. E. M.; VON WRIGHT, G. H. (Ed.). Oxford (UK): Blackwell Publishers, 1969.

WITTGENSTEIN, L. Da certeza. Tradução de Maria Elisa Costa. Lisboa: Edições 70, 1990.

WITTGENSTEIN, L. Philosophical Investigations. Translate by ANSCOMBE, G. E. M. Oxford (UK): Basil Blackwell, 1986.

WITTGENSTEIN, L. Philosophische Untersuchungen. Translated by ANSCOMBE, G. E. M.; HACKER, P. M. S.; and SCHULTE, Joachim. - Rev. $4^{\text {th }}$. ed. / by HACKER, P. M. S. and SCHULTE, Joachim. UK: Blackwell Publishing Ltd., 2009.

WITTGENSTEIN, L. Investigações filosóficas. Tradução de José Carlos Bruni. São Paulo: Abril Cultural, 1979.

WOLFREYS, J. Compreender Derrida. Petrópolis: Editora Vozes, 2009. 
